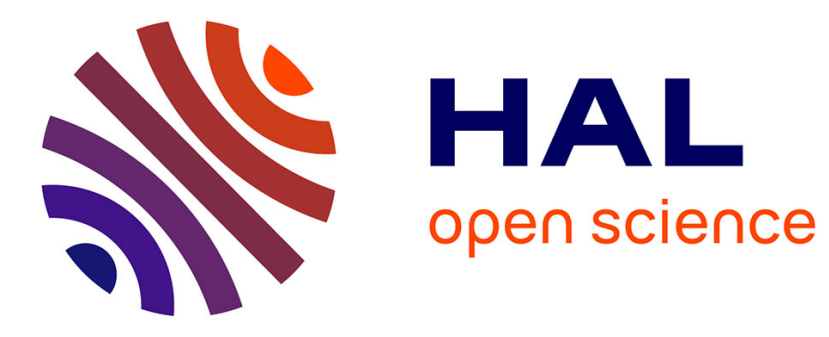

\title{
Micropedology to reveal pedogenetic processes in Technosols
}

Françoise Watteau, Geoffroy Séré, Hermine Huot, Frédéric Rees, Christophe Schwartz, Jean-Louis Morel

\section{- To cite this version:}

Françoise Watteau, Geoffroy Séré, Hermine Huot, Frédéric Rees, Christophe Schwartz, et al.. Micropedology to reveal pedogenetic processes in Technosols. Spanish Journal of Soil Science, 2018, 8 (2), pp.149-163. 10.3232/SJSS.2018.V8.N2.02 . hal-02173903

\section{HAL Id: hal-02173903 \\ https://hal.science/hal-02173903}

Submitted on 4 Jul 2019

HAL is a multi-disciplinary open access archive for the deposit and dissemination of scientific research documents, whether they are published or not. The documents may come from teaching and research institutions in France or abroad, or from public or private research centers.
L'archive ouverte pluridisciplinaire HAL, est destinée au dépôt et à la diffusion de documents scientifiques de niveau recherche, publiés ou non, émanant des établissements d'enseignement et de recherche français ou étrangers, des laboratoires publics ou privés. 


\title{
Micropedology to reveal pedogenetic processes in Technosols
}

\author{
Uso de la micropedología en la descripción de procesos edafogenéticos en Tecnosoles \\ Uso da micropedologia na descrição de processos pedogenéticos em Tecnossolos
}

\section{AUTHORS}

\section{Watteau F. ${ }^{\circledR, 1}$}

francoise.watteau@ univ-lorraine.fr

Huot H. ${ }^{1,2}$

Séré G. ${ }^{1}$

Begin J.C. ${ }^{1}$

Rees F. ${ }^{1}$

Schwartz C. ${ }^{1}$

Morel J.L. ${ }^{1}$

@ Corresponding Author

${ }^{1}$ Laboratoire Sols et Environnement, UL-INRA UMR 1120. F-54518

Vandœuvre-lès-Nancy, France.

${ }^{2}$ School of Environmental Science and Engineering, Sun Yat-sen University. 510275 Guangzhou, China.
Received: 30.03.2017 | Revised: 13.11.2017 | Accepted: 23.01.2018

\section{ABSTRACT}

Technosols are characterized by the presence of mineral and organic parent materials of technogenic origin (e.g. agricultural or urban wastes, industrial by-products, building materials, transported natural materials). In view of the continual increase of such man-made soils, there is a true need of understanding their functioning and evolution. Micropedology, i.e. morphological and analytical characterization of pedofeatures on soil sections, appears as a relevant approach to take into account the diversity and the specificity of Technosols in the knowledge of their pedogenetic processes. Micropedology was investigated at microscopic and submicroscopic scale on four Technosols. Therefore, it determined specific features of anthropogenic constituents allowing in situ monitoring until the early stages of Technosol pedogenesis. Organic matter dynamics, soil porosity evolution, impact of faunal activity or hydric conditions on Technosol structure were investigated. Moreover, as Technosol components and deposition modes are diverse, one can expect numerous interfaces. In that way, micropedology appeared particularly well adapted to study these local interfaces as sites of favoured pedogenesis. Supplemented with overall physico-chemical soil analyses, characterization of Technosol pedogenic features using micropedology improves the understanding of their functioning and evolution. In addition, according to the environmental context, such data also give useful information for the Technosol management.

\section{RESUMEN}

Los Tecnosoles se caracterizan por la presencia de materiales orgánicos y minerales de origen tecnogenético (p.ej. residuos agricolas o urbanos, subproductos industriales, materiales de construcción, materiales naturales transportados, etc.). Dado el aumento continuo de estos tipos de suelos antrópicos, es necesario comprender su funcionamiento y evolución. La micropedología, definida como la caracterización morfológica y analítica de microestructuras de láminas de suelo, es una herramienta estándar para el estudio de los mismos. La micropedología ofrece un enfoque relevante para el conocimiento de los procesos edafogenéticos de los Tecnosoles, ya que permite considerar la diversidad y la especificidad de los mismos. Cuatro tipos de Tecnosoles fueron investigados mediante técnicas de micropedología a escala fotónica y de ultraestructura. Asi, fue posible determinar las características de los constituyentes antropogénicos y realizar un seguimiento in situ hasta las fases tempranas de la edafogénesis de estos Tecnosoles. Se investigaron procesos como la dinámica de la materia orgánica, la evolución de la porosidad y el impacto de la actividad de la fauna o de las condiciones hidricas en la estructura de los Tecnosoles. Además, ya que los Tecnosoles son muy diversos tanto en sus componentes como en el modo en que estos componentes se organizan, es esperable que existan numerosas interfaces entre horizontes de suelo. De este modo, la micropedología se adapta muy bien al estudio de estas interfaces locales donde se dan procesos edafogenéticos. La caracterización micropedológica de las microestructuras de los Tecnosoles, complementada con análisis físico-químicos generales, incrementa de modo sustancial la comprensión 
de su funcionamiento y evolución. Por otra parte, y de acuerdo con el contexto ambiental, los datos micropedológicos suponen una información útil para la gestión de los Tecnosoles.

\section{RESUMO}

Os Tecnossolos são caracterizados pela presença de materiais minerais e orgânicos de origem tecnogénica (por exemplo, resíduos agrícolas ou urbanos, subprodutos industriais, materiais de construção, materiais naturais transportados). Considerando o contínuo aumento destes solos artificiais, é necessario compreender o seu funcionamento e evolução. A micropedologia, isto é, a caracterização morfológica e analitica de microestruturas em lâminas de solo, é uma abordagem relevante para o estudo dos Tecnossolos. A micropedologia oferece um enfoque particular para o conbecimento dos processos pedogenéticos dos Tecnossolos pois permite considerar a diversidade e especificidade dos mesmos. Quatro tipos de Tecnossolos foram investigados mediante técnicas de micropedologia às escalas microscópica and submicroscópica. Assim, foram determinadas caracteristicas especificas dos constituintes antrópicos, permitindo a sua monitorização in situ até os estádios iniciais da pedogénese dos Tecnossolos. A dinâmica da matéria orgânica, a evolução da porosidade do solo e o impacto da atividade da fauna ou das condiçóes hidricas na estrutura do Tecnossolo foram investigadas. Atendendo a que os Tecnossolos são muito diversos tanto em relação aos seus componentes, como ao modo como estes componentes se organizam, é expectável que existam numerosas interfaces entre horizontes do solo. Deste modo, a micropedologia é uma metodologia bem adaptada para o estudo destas interfaces locais onde os processos pedogenéticos ocorrem favoravelmente. A caracterização micropedológia das microestruturas dos Tecnossolos, complementada com análises físico-químicas do solo, aumenta de modo substancial a compreensão do seu funcionamento e evolução. Além disso, de acordo com o contexto ambiental, os dados micropedológicos também fornecem informações úteis para a gestão dos Tecnossolos.

\section{Introduction}

Technosols are characterized by a significant presence of mineral and organic materials of technogenic origin. They have been integrated as a reference in 2006 in the World Reference Base of Soil Resources (IUSS Working Group WRB 2006) at the initiative of the Working Group IUSS SUITMA (Soils of Urban, Industrial, Traffic, Mining and Military Areas). Their diversity, their potential contamination and the significant increase in their presence in the territories justify characterizing their functioning and evolution (Prokof'eva and Poputnikov 2010; Morel et al. 2014). In this way, Adderley et al. (2010) reported that Technosol micromorphology might improve the knowledge about the evolution and future management of such soils.

Soil micromorphology, which includes the study of soil in undisturbed state at the microscopic level, can provide a deeper understanding of the Anthropocene, as links between micromorphology and larger scales is examined (Monger and Cooke 2013). Soil feature characterization on thin sections is a significant tool to investigate pedogenic processes, such as mineral weathering, organic matter degradation, soil structure dynamics, leaching of particles (Stoops et al. 2010). Description of soil components or features often helped to identify processes involved in soil evolution during anthropization (e.g., Macphail et al. 1990; Ringrose-Voase 1991; Pagliai and Vittori Antisari 1993; Adesodun et al. 2005; 
Pulleman et al. 2005; Mazurek et al. 2016), and to differentiate impact of natural forces from anthropic ones. In Technosols, parent materials are mostly "artefacts" (e.g. disturbed pedological or geological materials, industrial by-products, building materials, agricultural or urban wastes; IUSS Working Group WRB 2006). These artefacts are still not as well described as natural soil components. So, there is a need to characterize them and also to monitor their evolution as they are subjected to the influence of pedogenic factors (e.g. time, climate, biological activity) in a similar manner than natural soils. Moreover, as Technosol components (e.g. natural and technogenic) and their deposition modes are diverse, one can expect numerous interfaces. Giving accurate results at fine scale, micropedology could be a suitable tool to study these interfaces and to highlight local specific pedogenetic processes in Technosols.

We present here the contribution of micropedology to the understanding of Technosol formation and functioning based on the study of 4 different Technosols, with varying parent materials, impact of human activities, vegetation cover and age. We conducted micromorphological studies on 3 constructed Technosols (Séré et al. 2010), a 60-year old Spolic Technosol developed on a highly polluted forested settling pond (Huot et al. 2014), a green roof soil (Schwager et al. 2013) and a biochar amended Luvisol (Rees et al. 2015). The first three Technosols were constructed or amended to fulfill specific functions (e.g. site reclamation, regulation of rainwater quantity). Such soils allowed us to monitor the evolution of the technogenic materials introduced and the soil structure dynamics from the early stages of pedogenesis. The Spolic Technosol was an ideal site to investigate the pedogenesis on pure technogenic materials and the functioning of a forest ecosystem on highly polluted soil. Morphological and analytical characterization on thin or ultra-thin sections were performed in order to characterize technogenic constituents, describe Technosol porosity and aggregation at different stages of pedogenesis and specify the impact of pedogenic factors (e.g. climatic and biological activity) on structure dynamics.

\section{Materials and Methods}

Four contrasted Technosols were chosen to illustrate the diversity of such anthropogenic soils:

1. a Constructed Technosol, i.e. Spolic Garbic Hydric Technosol (Calcaric) (IUSS Working Group 2015), comprising from top to bottom : i) green-waste compost horizon $(10 \mathrm{~cm})$ from urban trees and grass cuttings, ii) mixture $(1: 1 \mathrm{v} / \mathrm{v})$ of paper-mill sludge and thermally treated industrial material extracted from a former coking plant $(80 \mathrm{~cm})$, and iii) pure papermill sludge $(25 \mathrm{~cm})$; this Technosol has been implemented on field tests in 2003 at the GISFI experimental station (www.gisfi.fr) in the east of France. Plots of $150 \mathrm{~m}^{3}$ were filled with layers of technogenic parent materials. Soil was initially left unplanted, then colonized by spontaneous vegetation before being seeded by Rye grass and alfalfa (Séré et al. 2010). Undisturbed soil samples were regularly taken over the entire soil depth and particularly at the interfaces between the different layers. The process of soil construction for the reclamation of derelict lands is based on the recycling of secondary byproducts. Based on the pedological engineering concepts, these artefacts are combined to construct a new soil (constructed Technosol) over in situ brownfield substrates. Our work aims at understanding and predicting the pedogenic processes and assessing the sustainability of such Technosols. Moreover, as the initial characteristics of constructed Technosols are controlled and well known, they represent unique experimental models for studying the early stages of soil formation.

2. a Spolic Technosol (Andic, Calcaric, Hydric, Laxic, Thixotropic, Toxic) (IUSS Working Group 2015) has developed for 60 years in the east of France on a 2.6-ha settling pond filled with blast furnace sludge from the iron and steel industry (Huot et al. 2014). Metals in this soil were at very high concentrations (up to $10 \%$ for $\mathrm{Zn}, 8 \%$ for $\mathrm{Pb}$, depending on soil layers). Despite this pollution, a true forested ecosystem has developed, thereby offering an original site to study the link between pedogenesis and biodiversity on pure technogenic materials. 
3. an Isolatic Technosol (Drainic, Folic, and Transportic) (IUSS Working Group 2015) developed in a 6-year old green roof soil, consisting of $80 \%$ pozzolana, and $10 \%$ Baltic blond peat and $10 \%$ Pinus pinaster bark in the east of France (Schwager et al. 2013; Bouzouidja et al. 2016). This $10-\mathrm{cm}$ thick substrate layer was set on a $4-5 \mathrm{~cm}$ thick drainage layer of gravel. A classical set of six sedums (Sedum album, Sedum reflexum larix, Sedum reflexum germanium, Sedum spurium, Sedum sexangulare, Sedum floriferum) has been introduced on the green roof. Green roofs are increasingly widespread in dense urban areas due to their multiple potential functions and the possibility of building them on sub-exploited surfaces. Current water quality and water bodies' protection objectives should take into account the quality of all urban runoff, including storm water. It is consequently necessary to understand the mechanisms inducing potential water quality degradation on green roofs in both the short and long term, in order to avoid these pitfalls for future green roof construction and potentially enhance their ability to retain atmospheric pollutants. The micromorphology was therefore assessed to survey the structure evolution in these soils.

4. a biochar-amended Cambic Stagnic Luvisol. Two undisturbed $2 \mathrm{~m}^{3}$ soil monoliths were sampled in Evin-Malmaison (North of France) in 2009 and installed in two lysimeters (GISFI experimental station, Homécourt, France). As a consequence of the high contamination of $\mathrm{Zn}$, $\mathrm{Pb}$ and $\mathrm{Cd}$, the top $30-\mathrm{cm}$ in one of the two soil columns was amended with a wood derivedbiochar ( $5 \%$ in weight, $\sim 15 \%$ in volume) in order to modify soil metal availability (Rees et al. 2015). The top 30-cm of both columns was excavated in March 2013, homogenized and air-dried until reaching an optimal water content for soil mixing. Biochar was manually mixed with the soil from one column in 10-kg batches. The amended soil was placed back at the top of the corresponding lysimeter, and seedlings of Noccaea caerulescens were introduced 4 weeks later (124 plants per $\mathrm{m}^{2}$ ). The control lysimeter underwent the same procedure as the amended one, without biochar addition. Thin sections were prepared from undisturbed soil sampled between 5 and $20 \mathrm{~cm}$ depth on each lysimeter in October 2013. Over the 6-month period prior to the sampling, both lysimeters had been exposed to atmospheric precipitations (input of water as rain: $~ 350 \mathrm{~mm}$; output as leachate at 1.85-m depth: $\sim 150 \mathrm{~mm}$ ). Although it concerned a lysimeter study and so, not classified as real Technosol according to the WRB, the biocharamended soil was added to this study as an opportunity to investigate the redistribution of technogenic material (biochar) introduced in soil.

In the text, the following abbreviations corresponding to the 4 different studied Technosols will be used, i.e. Constructed Technosol, Spolic Technosol, Isolatic Technosol and biochar-amended Luvisol (see Table 1 for the main characteristics).

Soil cores were sampled in Kubiena boxes $(9 \times 6 \mathrm{~cm})$ in horizons or at the interface between twolayers. Soil thin sections $(20 \mu \mathrm{m}$-thick, $9 \times 6 \mathrm{~cm})$ were prepared according to the technique described by Jongerius and Heinzberger (1975). The soil samples were dried by replacing water by acetone. This step was important, as slower dehydration was necessary in order to take into account the specific properties of organic technogenic materials (hydrophobicity of organic pollutants or high water holding capacity of paper mill sludge). Soil samples were then impregnated under vacuum with polyester resin. The consolidated bloc was cut into two equivalent parts. One part was fixed on a thin glass of the same size $(9 \times 6 \mathrm{~cm})$ and ground to $20 \mu \mathrm{m}$. Total thin sections were scanned using a flatbed scanner (EPSON V750 Perfection Pro) at 1200 dpi. Magnified images were obtained with a Leica stereomicroscope MZ FLIII microscope. Some of the thin sections were cut for analysis with a JEOL scanning electron microscope (SEM) equipped with an EDS analysis system after thin carbon coating. Ultra-thin sections (80 $\mathrm{nm}$ thick) of soil structures were also prepared for observation by transmission electronic microscopy (TEM) (JEOL EXII - 80 $\mathrm{kV}$ ) according to a protocol that preserved the initial structures (Watteau et al. 2012). TEM-EDX analyses were done on non-contrasted ultra-thin sections by using an EDS spectrometer, Silicon Drift detector (PGT) associated to the TEM JEOL EXII. 
Table 1. Main characteristics of the different soils

\begin{tabular}{|c|c|c|c|c|}
\hline Soils & $\begin{array}{l}\text { Constructed } \\
\text { Technosol }\end{array}$ & $\begin{array}{c}\text { Spolic } \\
\text { Technosol }\end{array}$ & Isolatic Technosol & $\begin{array}{c}\text { Biochar amended } \\
\text { Luvisol }\end{array}$ \\
\hline Age & 3 years & 60 years & 6 years & 4 years \\
\hline Vegetation & $\begin{array}{l}\text { Spontaneous vegeta- } \\
\text { tion then seeded with } \\
\text { Rye grass and alfafa }\end{array}$ & Forested ecosystem & Set of six sedums & $\begin{array}{l}\text { Seeded with Noc- } \\
\text { caea caerulescens }\end{array}$ \\
\hline Parent materials & $\begin{array}{l}3 \text { layers, from top to } \\
\text { bottom: GW com- } \\
\text { post, PS mixed with } \\
\text { TIM, pure PS }\end{array}$ & $\begin{array}{l}\text { Blast furnace sludge } \\
\text { from iron and steel } \\
\text { industry }\end{array}$ & $\begin{array}{l}\text { Pozzolona, Baltic } \\
\text { blond peat and Pinus } \\
\text { pinaster barks }\end{array}$ & $\begin{array}{l}\text { Highly polluted indus- } \\
\text { trial soil and biochar }\end{array}$ \\
\hline $\begin{array}{l}\text { Experimental } \\
\text { design }\end{array}$ & $\begin{array}{l}\text { Plots of } 150 \mathrm{~m}^{2} \text { in } \\
\text { field conditions }\end{array}$ & 2.6 ha settling pond & Roof soil & $\begin{array}{c}2 \mathrm{~m}^{3} \text { soil monoliths in } \\
\text { lysimeters }\end{array}$ \\
\hline pH & 8 & 7.8 to 8.4 & 6.8 & 8.1 \\
\hline $\begin{array}{l}\text { Organic matter } \\
\left(\mathrm{g} \mathrm{kg}^{-1}\right)\end{array}$ & 70 & $55^{*}$ & 88 & 18.8 \\
\hline $\begin{array}{l}\text { Coarse materials } \\
50-2000 \mu \mathrm{m}\left(\mathrm{g} \mathrm{kg}^{-1}\right)\end{array}$ & 820 & $180^{*}$ & 150 & 180 \\
\hline
\end{tabular}

GW compost: green waste compost; PS: paper mill sludge; TIM: treated Industrial material; *: mean of the different layers.

\section{Results and Discussion}

3.1. Mineral and organic artefacts in the Constructed Technosol

Parent materials were set up in the plots in 2003. A strong evolution of the profiles was observed over the first 3 years with rapid changes in the number and characteristics of the horizons (Figure 1). In addition to this increase in soil structure, results also showed a significant decarbonatation and a massive dissolution of gypsum (Séré et al. 2010). Figure 1 shows soil sections made 30 months after the set up. Differently sized mineral particles could be observed, from very coarse to finer ones. An organo-mineral matrix, compost layer and paper-mill sludge layer were identified and formation of aggregates was traced. Overall description of replicates and comparison over time of the different sections allowed us (i) to evaluate the diversity of size and nature of the different organo-mineral associations and (ii) to differentiate the initial associations due to the soil formulation from the pedogenic aggregates.
Observation at higher magnification underlined the heterogeneity and the broad range of particle sizes of the mineral components (Figure 2). Composite minerals were observed as bulk phases (Figure 2.1) or isolated particles (Figure 2.2). Their presence was partially due to the formulation of the soil itself as during the set up and the mixture of the parent materials, mineral particles were partially crushed. The dissociation of the composite mineral particles was also probably due to potential weakness areas at the contact between the different phases (Figures 2.3 and 2.4). This shows the importance of observing interfaces as preferential weathering sites during the soil evolution. SEM/EDS analyses showed the multiphase nature of such mineral particles, composed of siliceous, carbonate and ironassociated phases (Figures 2.5 and 2.6). The presence of an amorphous siliceous phase and the juxtaposition of such different phases in the same particle was linked to the decontamination process of the initial industrial material (thermal treatment). Such specificities of technogenic mineral particles revealed by micromorphology, together with the chemical composition of the soil and leachates, will help complete our understanding of pedogenic processes over time. 

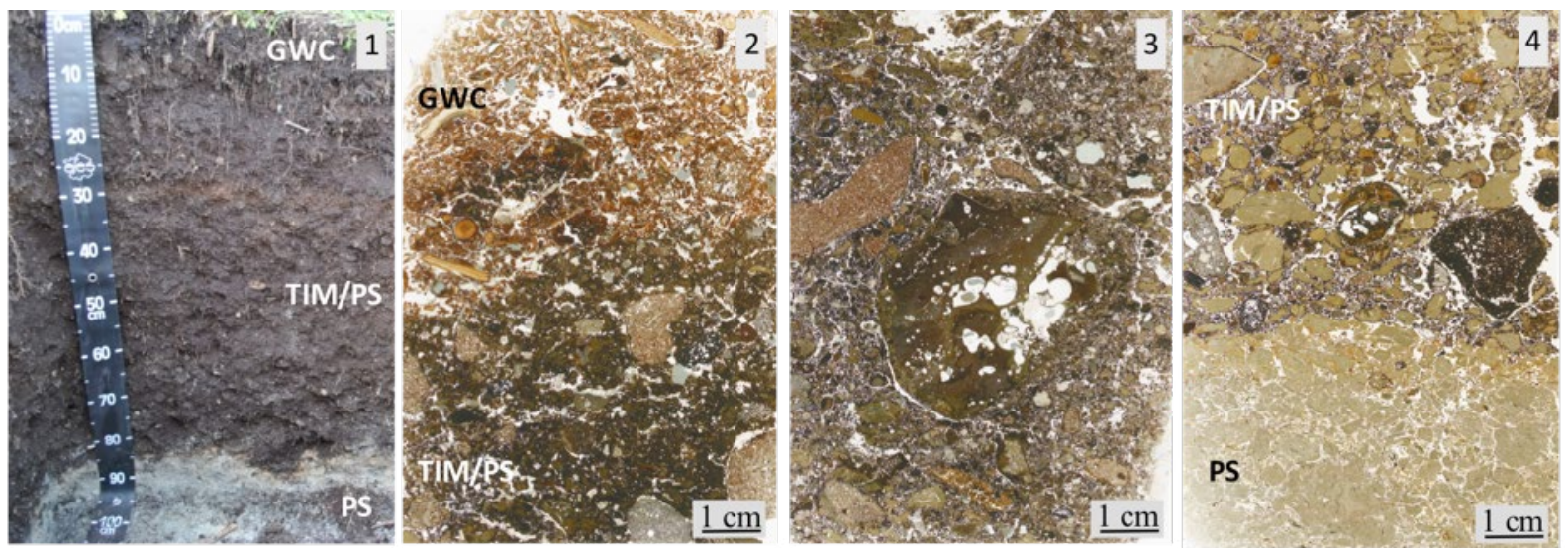

Figure 1. Profile and thin sections of Constructed Technosol realized 30 months after the set up. 1: soil profile showing the 3 layers; 2: thin section at the interface between the compost (GWC) and the TIM/PS layer; 3: thin section of the TIM/PS layer showing several coarse minerals surrounded by organo-mineral matrix; 4: thin section between TIM/PS and PS layer composed of nodules of cellulosic fibres. GWC: green waste compost; TIM: thermally treated industrial material; PS: paper-mill sludge.
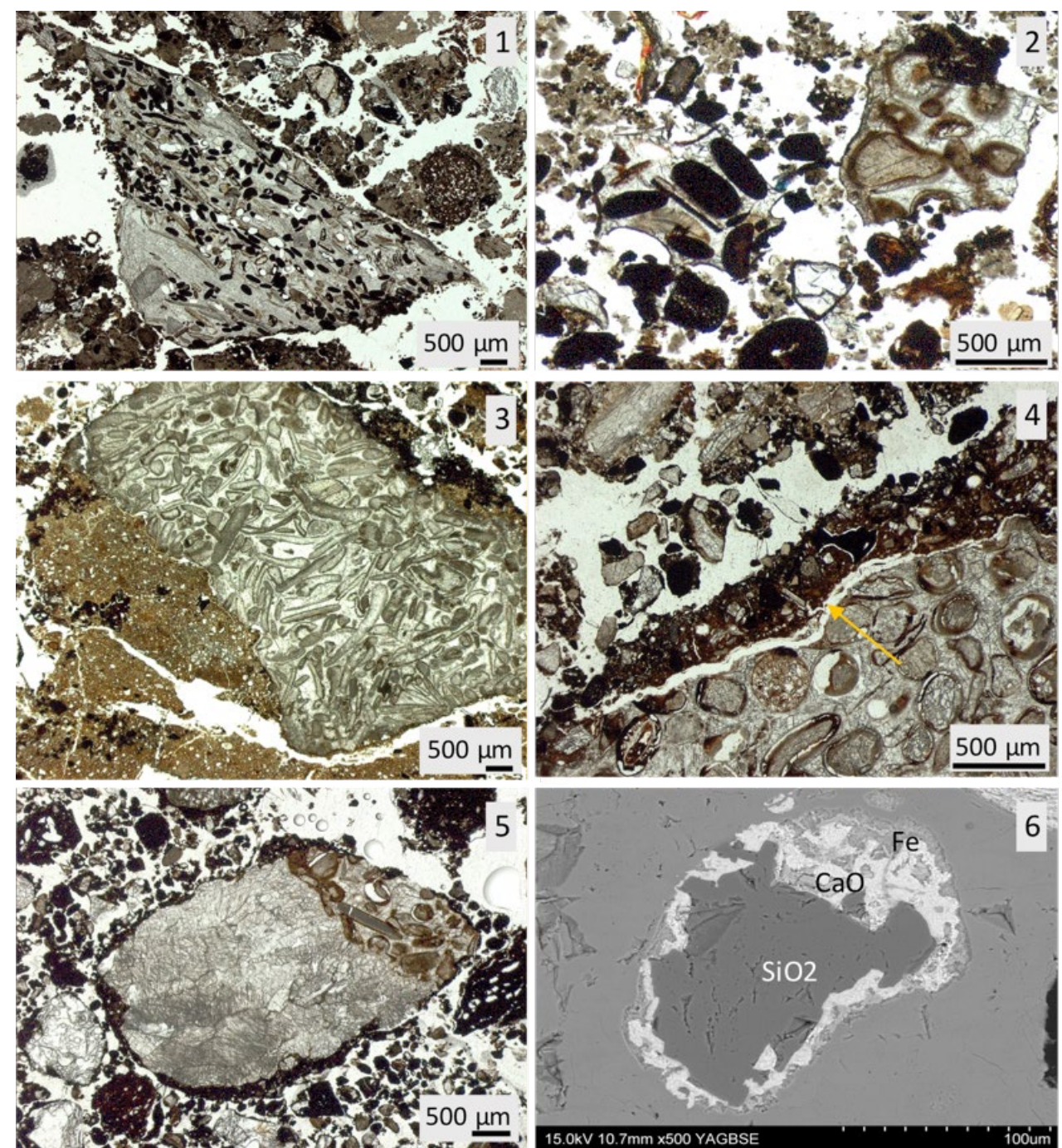

Figure 2. Mineral particles observed in thin sections of the Constructed Technosol. 1: coarse composite mineral particle surrounded by smaller ones; 2: dispersed particles as details of the different constituents of the coarse mineral in Figure 1; 3 and 4: composite mineral particle and detail of the interface between two different phases (see arrow); 5 and 6: mineral particle and SEM/EDS characterization (EDS spectra not shown). 
At the set-up of the experimental plots, organic components of the Constructed Technosol were brought (i) by green waste compost in the superficial layer and (ii) by paper-mill sludge in the two underlying horizons. Standard features of organic matter were recognized in the compost as they looked like humus material: differentlysized, more or less biodegraded, fragments of leaves, roots, twigs or bark (Figure 3.1). If plant tissues were visualised in thin soil sections, TEM observations revealed the microbial potential simultaneously brought by compost (Figure 3.2).
Bacteria, spores or microbial residues (or fungi, not shown here) could so be added by parent material in the profile. As the status of the microbial input depends on the stability/maturity of the compost (Watteau and Villemin 2011), the choice of the compost as organic layer could impact the organic matter dynamics in the Technosol profile. Faunal activity degraded the organic phase of the compost as faecal pellets of mites or isopods, which were increasingly observed over time (Figures 3.3 and 3.4).

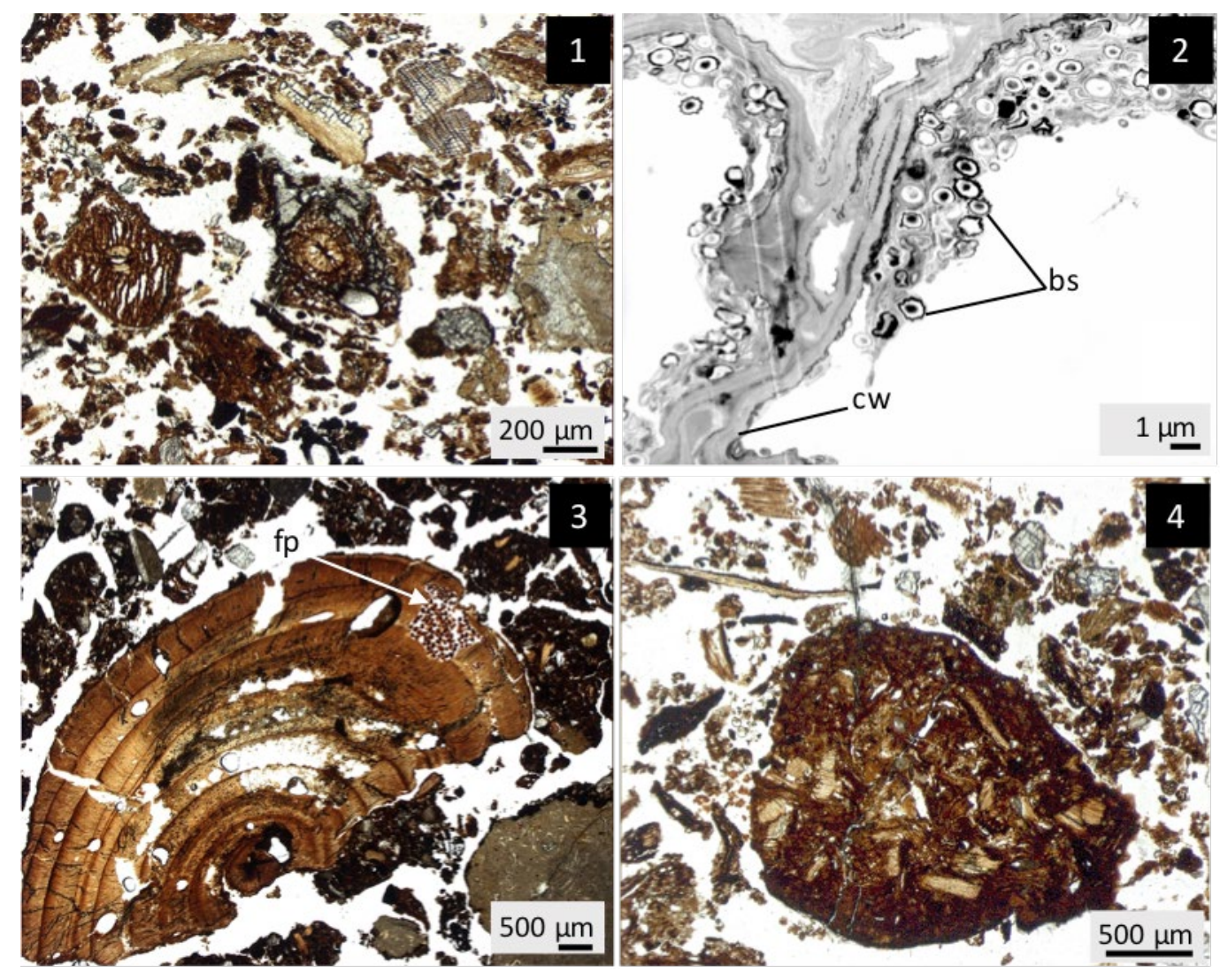

Figure 3. Organic components observed on thin and ultra-thin sections of the Constructed Technosol. 1: fragments of organic matter of the green waste compost; 2: TEM view of bacterial potential associated with cell wall of compost fragment; 3 : faecal pellets of mites in wood tissues; 4 : faecal pellet of isopod. bs: bacterial spore; cw: plant cell wall; fp: faecal pellet.

More unusually observed organic matter were the cellulosic fibres of the paper-mill sludge (PS) (Figure 4). They appeared as porous lightcoloured masses forming aggregates of different sizes (Figure 4.1). Some little fragments of contrasted colours (blue, red, yellow) were also observed within the fibres and were identified as plastic residues, initially contained in the
PS. From a strictly methodological point of view, such residues could be used as relevant indicators of the initial presence of PS over time, e.g. within soil aggregates. As the compost, PS was associated with microorganisms, bacteria and fungi (Figures 4.2 and 4.3). This means that Constructed Technosol formulation corresponded not only to the introduction of 
organic matter in depth, but also to an associated microbial potential. Impact of cellulolytic activity of these microorganisms (not shown here) on the degradation of the fibres has to be taken into account. Intrinsic water retention capacity of such parent material is expected and it could be altered in the case of microbial degradation of the fibres. Micromorphology also underlined some evolution features of PS: orange colour and fragmentation in small nodules $(20-30 \mu \mathrm{m})$ (Figures 4.4 and 4.5). Iron $\left(\mathrm{FeCl}_{3}\right)$ was added as a flocculation agent during the industrial process of PS production and so became associated with cellulosic fibres. Humectation/desiccation cycles in the Technosol profile probably changed the iron status, thereby inducing the oxidationreduction traces seen in thin section. Local soil conditions (e.g. water content or $\mathrm{O}_{2}$, depth, etc.) probably impacted the formation of the small nodules. Micromorphology underlined some modifications of the fibres, which still remain to be linked to a potential modification of their physico-chemical characteristics (e.g. water retention and restitution).

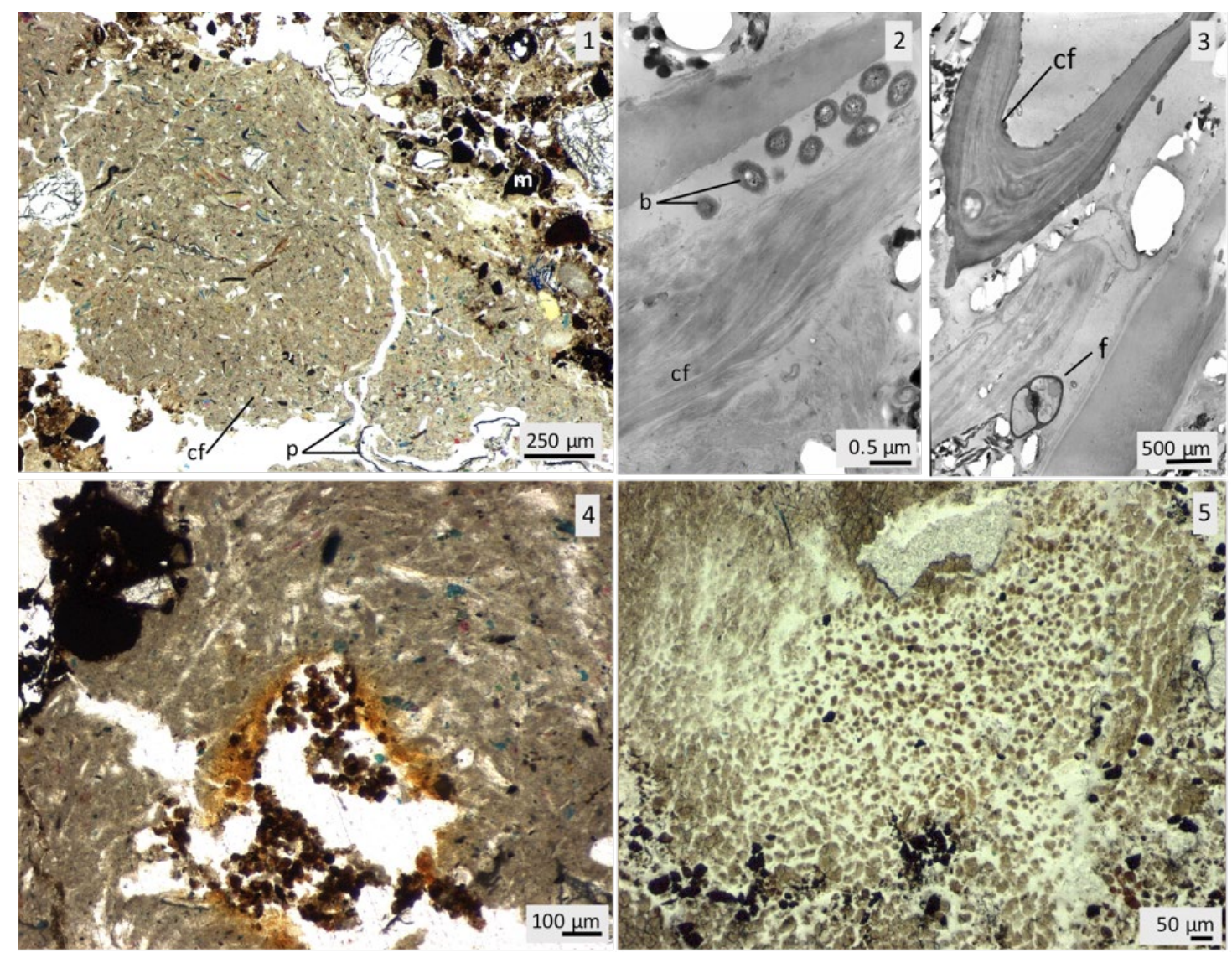

Figure 4. Paper-mill sludge of the Constructed Technosol. 1: structure of cellulosic fibres observed in thin section; 2 and 3: TEM observations of the microbial potential associated with cellulosic fibres; 4 and 5 : modifications of the tint and the structure of the cellulosic fibres observed in thin sections. b: bacteria; cf: cellulosic fibre; f: fungus; m: mineral; $p$ : plastic fragment.

Organo-mineral aggregates were also characterized in thin sections (Figure 5). These aggregates could be either man-made in origin, as association between PS and minerals from the treated industrial material (TIM) due to the initial soil formulation (Figure 5.1), or from faunal activity, as earthworm faeces gathered the three parent materials (Figure 5.2). Associations between plant residues from compost and minerals from TIM were also observed by TEM, underlining the contribution of degraded plant materials by bacteria to microstructures (Figure 5.3). Microbial micro-aggregates (i.e. bacteria producing exopolymers on which minerals adhere) were also involved in the Technosol structure (Séré et al. 2010). 
Thus, the Constructed Technosol micropedology gives relevant indicators at different time steps on the behaviour of artefacts, notably considering the soil structure, from the initial mixtures of parent materials to the evolved soil after some years. This methodological approach is well adapted to the spatial heterogeneity displayed

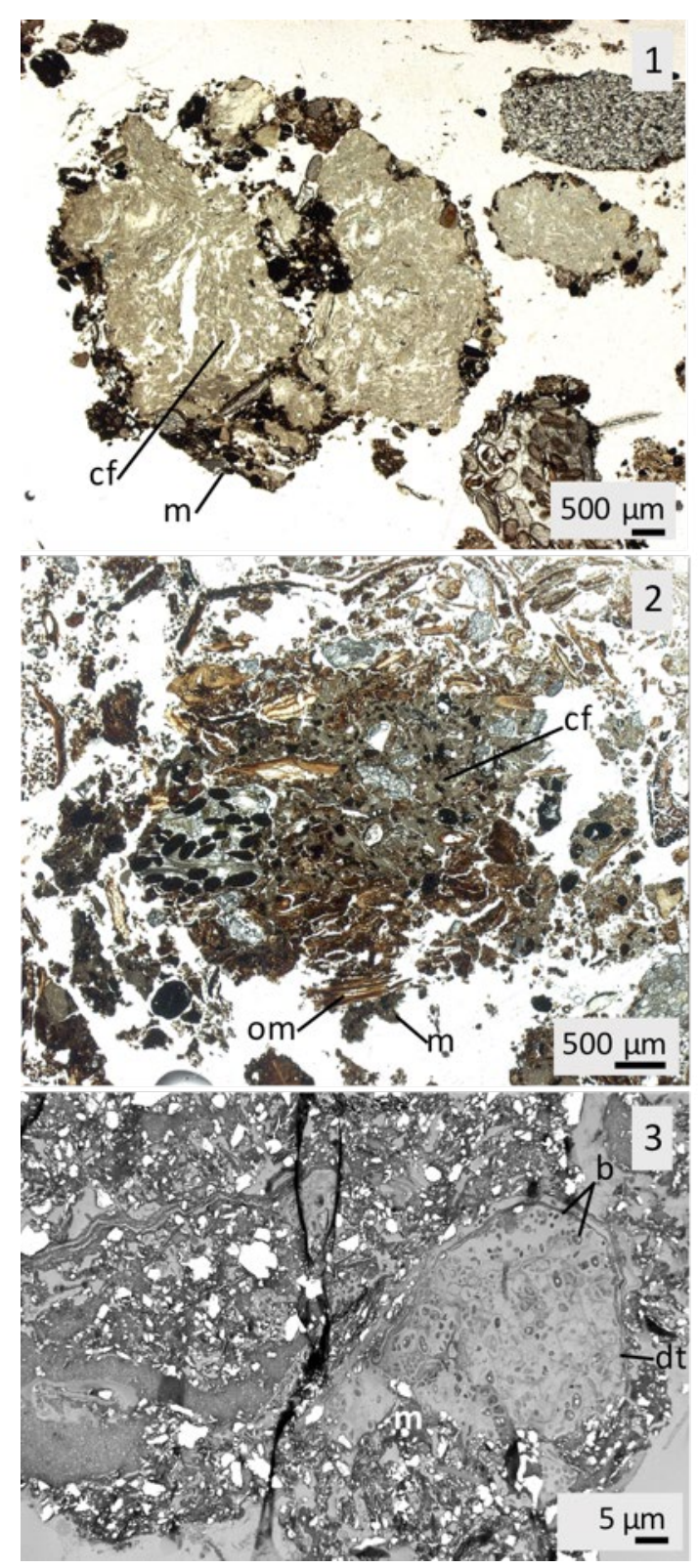

Figure 5. Organo-mineral aggregates of the Constructed Technosol. 1: association between paper sludge and industrial material observed in thin section; 2: earthworm faeces observed in thin section; 3: TEM observation of plant tissues degraded by bacteria in association with mineral particles of the industrial material. b: bacteria; cf: cellulosic fibre; dt: degraded plant tissue; m: mineral; om: organic matter. by Technosols and also to the diversity of used parent materials. Moreover, as for natural soils, micropedology can be used to observe the input of natural organic matter from roots and leaf of colonising vegetation and monitor its evolution in connection with the evolution of anthropogenic organic matter.

\subsection{Pedogenic processes by means of Technosol structure dynamics}

\subsubsection{Spolic Technosol}

The Spolic Technosol profile developed on the settling pond of iron and steel industry was composed of a superimposition of subhorizontal layers of various colours, thickness and structure (Figure 6.1). This laminar structure was due to the succession over time of sludge deposits. These layers were arranged in two groups according to their structure and composition, linked to the composition of the industrial effluent. Group 1 was composed of iron-, carbonate- and aluminosilicate-rich layers exhibiting a compact structure. Group 2 contained manganeserich layers with a friable structure (Huot et al. 2014). Series of cracks intersected these laminar layers along the Technosol profile and were particularly detected at some interfaces between them (Figure 6.2). These cracks were mainly filled with fine materials originating from the layers above (Figures 6.2 and 6.3) and must result from humectation/desiccation cycles. Assuming a discontinuous discharge of the sludge, desiccation periods may have affected some deposits. The cracks were then filled with the material of the upper layer by the fine particles. Areas with a particulate structure could result from the departure of these fine particles. Cracks could also favor the precipitation of metals, that were solubilized then transported by water, leading to their coating after an oxidationreduction process and the formation of nodules rich in these elements (e.g. Mn, $\mathrm{Pb}$, shown by SEM/EDS analyses of thin sections in Huot et al. 2014). Here, micropedology confirmed the coexistence of processes rarely encountered simultaneously in natural environments but occurring in volcanic soils, carbonated soils and hydromorphic soils respectively (Huot et al. 2014, 2015). 

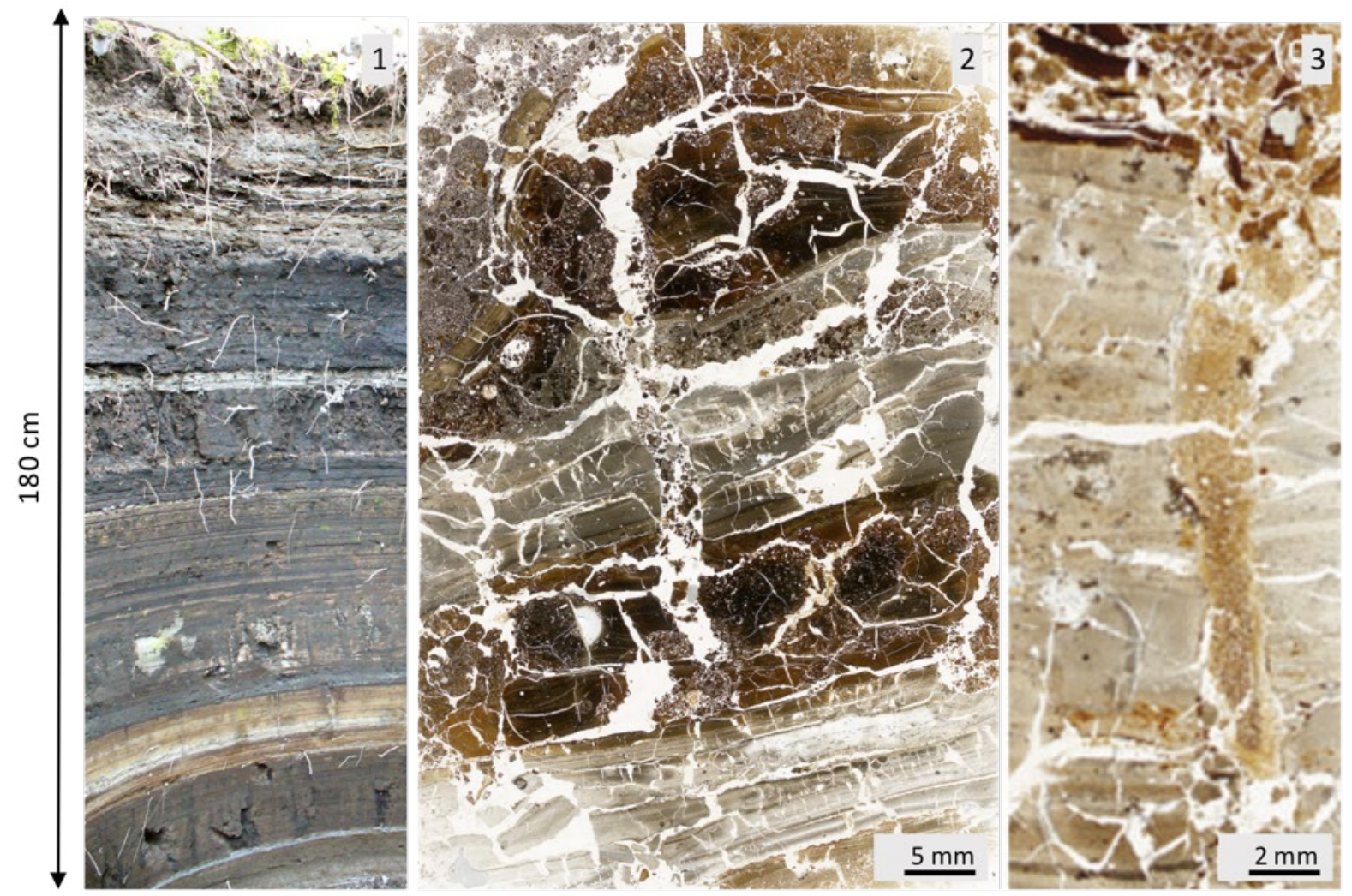

Figure 6. Profile and thin sections of the Spolic Technosol. 1: soil profile; 2: thin section showing cracks intersecting laminar layers $(26-35 \mathrm{~cm})$; 3 : crack filled with the material of the above layer $(65-68 \mathrm{~cm})$.

\subsubsection{Biochar-amended Luvisol}

The observation of thin sections of an agricultural soil 6 months after the introduction of a large amount of wood-derived biochar particles of various size also enabled us to assess whether the leaching of the introduced biochar particles i.e., their physical migration downwards the topsoil horizon, would constitute a significant pedological process to take into account in the early evolution of biochar-containing Technosols. Thin sections of the biochar amended Luvisol showed that large particles were homogeneously distributed in the amended horizon, but also that small biochar particles $(<50 \mu \mathrm{m})$ were mostly located around soil aggregates (Figure 7.1). A closer look at the thin sections under a stereomicroscope suggested that at least a part of the small biochar particles may have migrated through the macropores formed around large soil aggregates, and may have been subsequently deposited at the surface of some of these aggregates (Figures 7.2 and 7.3). Moreover, most of the distinguishable roots of Noccea caerulescens which grew in the biocharamended soils were partially or entirely coated with fine particles of biochar $(\sim 10 \mu \mathrm{m})$. We verified that the protocol of resin impregnation itself did not cause this apparent coating, by observing additional thin sections prepared from artificial soil cores containing various amounts of roots, soil materials and biochar. No similar coating of roots or large soil aggregates were observed in these artificial conditions (data not shown), suggesting that this phenomenon of fine particles migration and fixation only occurred as a result of environmental processes. It is likely that water percolation and water uptake by roots play an important role in the movement and fixation of these fine biochar particles. These findings may have important consequences for the functioning of the soil-plant system. The impact of biochar on plants may indeed be exacerbated by this coating phenomenon, as most of the 

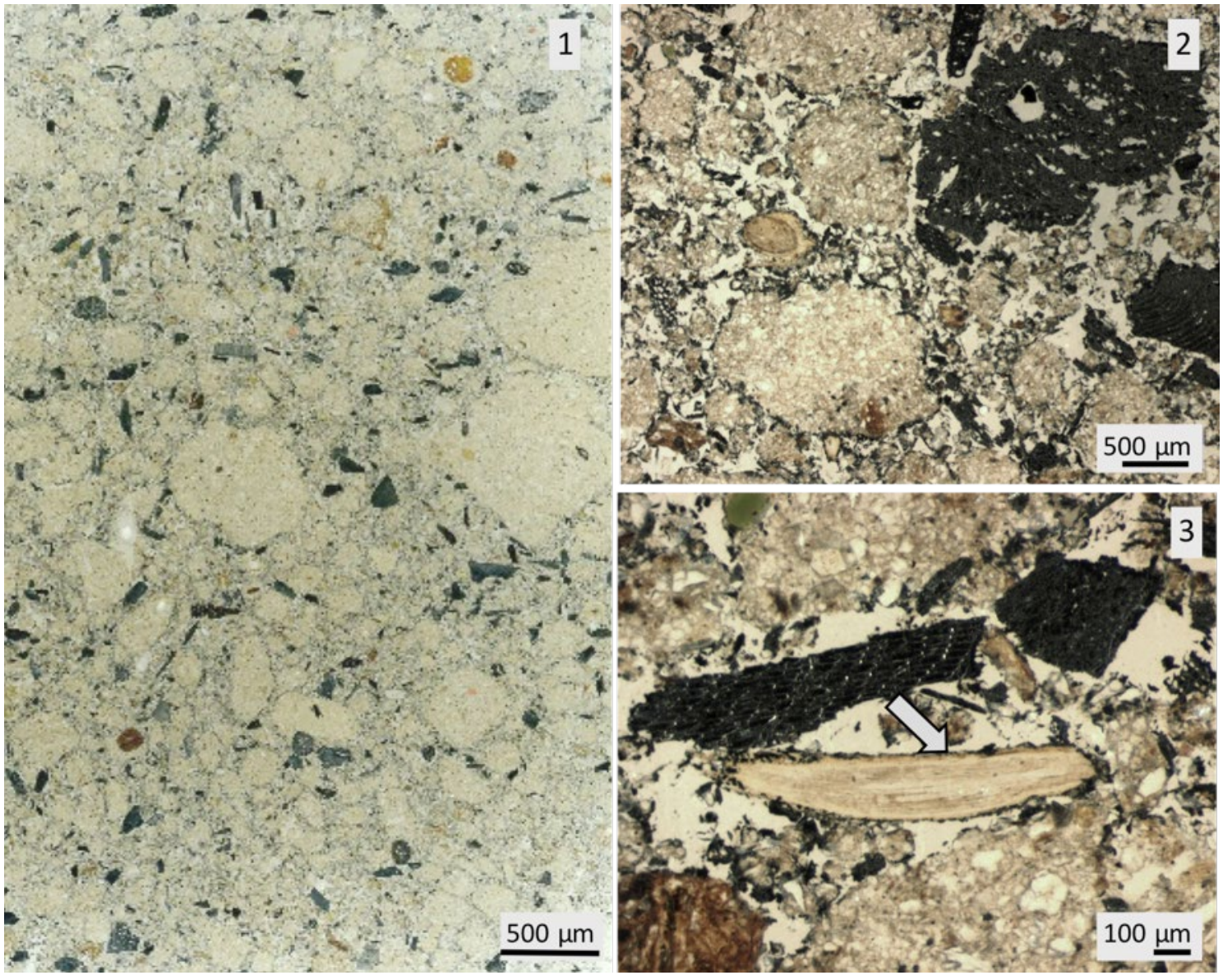

Figure 7. Thin sections of biochar amended Luvisol. 1: large and small biochars (in black); 2 and 3: isolated large biochars and small biochars around aggregates and roots (arrow showing biochar around root).

root surface would then be in contact with fine biochar particles despite the correspondingly low mass of biochar represented by these particles. This micromorphological approach also demonstrates that fine biochar particles can be mobilized and concentrated at certain spots in the soil in less than 6 months, suggesting a fast rearrangement of soil structure in these biochar-amended soils.

\subsubsection{Constructed Technosol}

Some research on Constructed Technosols (set up in plots of 1 ha; Jangorzo et al. 2013, 2014) concerned the structure descriptors of thin sections. Image analysis procedures from thin sections were developed to quantify porosity and aggregation evolution two years after the set-up of the field test. Results shown that soil compaction was mainly due to the decrease of the number and surface area of large pores (packing pores) with equivalent diameters exceeding $2000 \mu \mathrm{m}$. This is due to a resting state of the soil following a perturbation state as the soil was constructed (excavation of soil materials, waste production, drying, transport, mixture and arrangement in layers). After statistical analysis, descriptors of pores and aggregates were proposed as indicators to be monitored in the study of Technosol structure evolution during the early stages of pedogenesis (Jangorzo et al. 2013, 2014). Micropedology, including observation and quantification of descriptors of soil porosity and aggregation, appears to be a relevant tool to monitor constructed Technosol structure.

Soil structure results from the pedogenesis and can be considered as an indicator of soil functioning and evolution. Results showed that micropedology improves the understanding of 
Technosol structure dynamics. It allowed us to highlight some specific pedogenetic processes occurring at the microscale, which would have been difficult to measure with global physicochemical analyses. Due to the experimental setup, such approaches allow us to study Technosol structure from the first stages of pedogenesis and the used methodology is well adapted to monitor the rapid modifications of pedogenetic processes observed in such soils. Quantification of structure descriptors at microscale advantageously completed morphological observations in the experimentations, both in situ and in laboratory. Such approach is expected to give data for modelling the Technosol structure dynamics.

3.3. Impact of biological activity on Technosol structure

\subsubsection{Roots}

All Technosols studied supported vegetation, either planted or spontaneously established. In complement to root profile description, Technosol thin sections allowed us to characterize the presence and the degradation state of roots in the different layers and particularly with soil depth. Thus, roots were even observed at the bottom (105 cm depth) of the profile in the paper-mill sludge layer of the Constructed Technosol (Figure 8.1) and at $85 \mathrm{~cm}$ depth of the Spolic Technosol as they were growing in cracks coated by materials rich in pollutants $(\mathrm{Mn}, \mathrm{Pb}$ ) (Figure 8.2). In both cases, roots were numerous and active. Moreover, root activity was closely associated with microbial activity (e.g. in the Constructed Technosol, Figure 8.3). Bacteria were present at the interface between roots and soil. Their adhesion was favoured by the production of exopolymers (Figure 8.3). Otherwise, in the Isolatic Technosol on the green roof, the use of pozzolana induced high porosity between the particles that are preferential paths for root growth (Figure 8.4). In this thin section intra-particle porosity was also significant. After a few years, organic matter and roots could be frequently observed in this intra-particle porosity (Figures 8.5 and 8.6). Therefore, micropedology offers a relevant way to monitor the needed drainage capacity of such roof

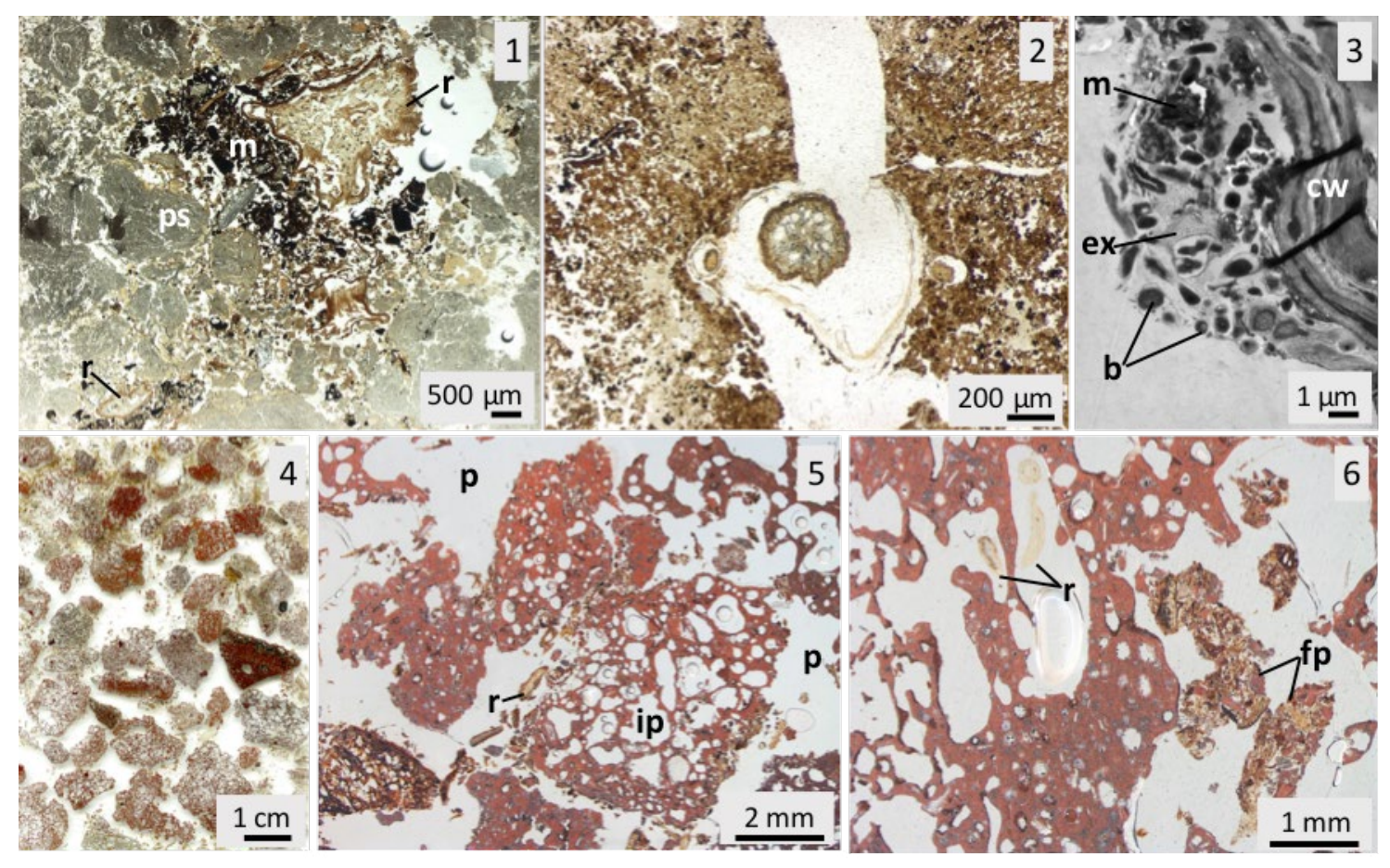

Figure 8. Roots in Technosols. 1: thin section of the Constructed Technosol showing roots at the bottom of the profile in the PS layer; 2: thin section of the Spolic Technosol showing roots in cracks at $85 \mathrm{~cm}$ depth; 3: TEM observation of the interface root/ Constructed Technosol; 4, 5 and 6: thin sections of the Isolatic Technosol on green roof showing roots in the porosity of the pozzolana. b: bacteria; cw: plant cell wall; ex: exopolymer; fp: faecal pellet; ip: intra-particle porosity; m: mineral; p: pore between pozzolana particles; ps: paper-mill sludge; r: root. 
materials according to vegetation growth. As in standard soils, roots will impact the Technosol structure during their growth, e.g. by modifying porosity (Jangorzo et al. 2015), introducing root organic matter (exudation and exfoliation) in the different soil layers or inducing aggregation. So, root characterization on thin Technosol sections helps to describe their impact on the dynamics of organic matter decomposition and structure development, as they were growing within an anthropic system.

\subsubsection{Faunal activity}

Numerous faecal pellets of mites or isopods were observed in the superficial layer of the Spolic Technosol (Figure 9.1), thereby underlining their impact on the organic matter dynamics. SEM/EDS analyses of these pellets emphasized the presence of minerals within (Figure 9.2). Moreover, these minerals also contained $\mathrm{Mn}$ and $\mathrm{Pb}$ (Figure 9.3) whereas the organic part of the pellets was associated with
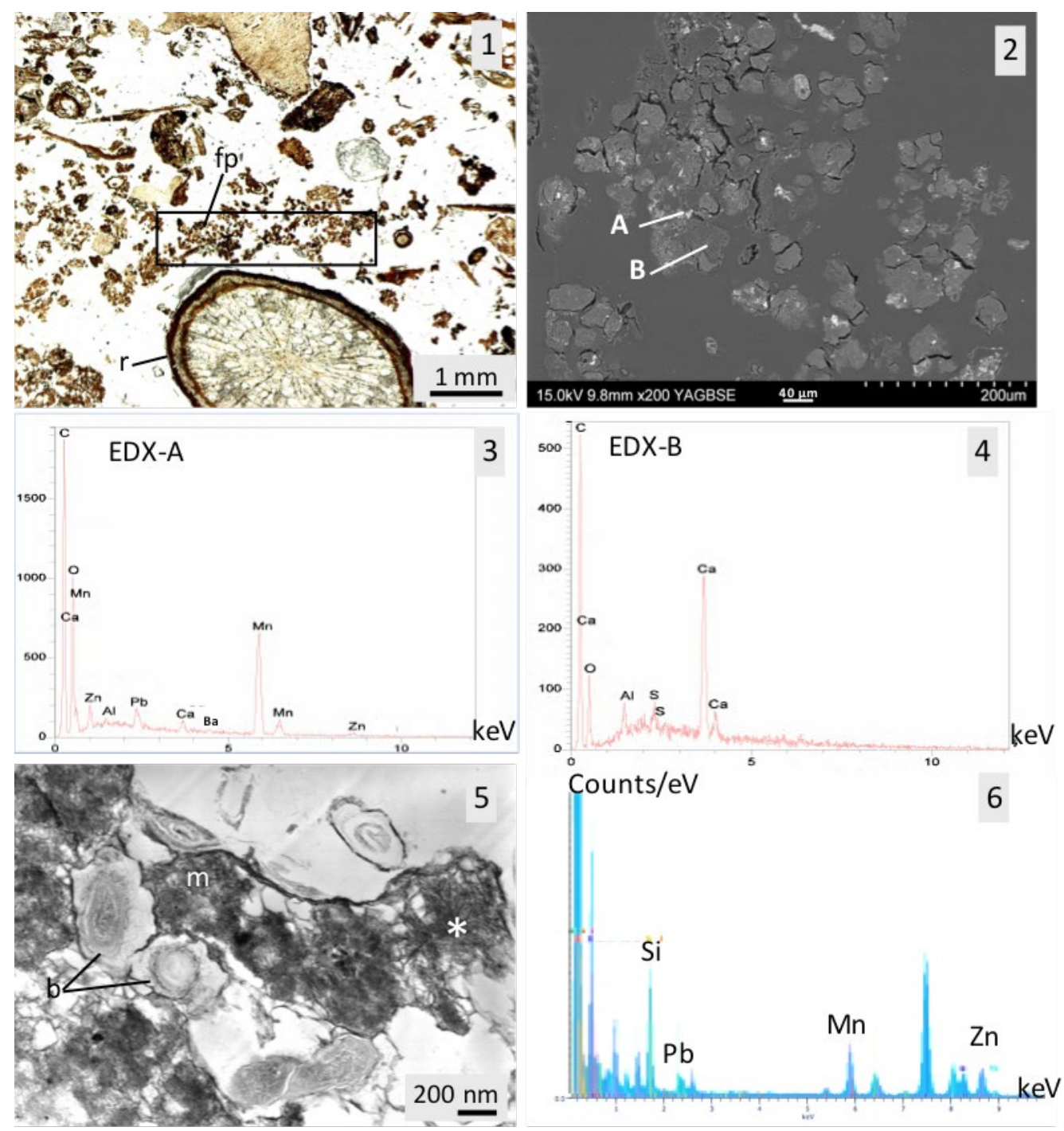

Figure 9. Faunal and microbial activity in the Spolic Technosol. 1: thin section of the superficial layer showing faecal pellets (frame); SEM observation of the faecal pellets and localization of the EDS analyses, A and B corresponding respectively to the mineral and organic part of the pellets; 3 and 4: SEM-EDX-A and SEM-EDX-B spectra corresponding respectively to the mineral and organic part of the pellets; 5 : TEM view of bacteria associated with minerals; 6 : TEM-EDX analysis of the mineral. b: bacteria; fp: faecal pellet; m: mineral; r: root ; * localization of the EDX analysis. 
Ca (Figure 9.4). Thus, microarthropods could ingest such polluted materials and redistribute them via their excrements while they moved in the soil. Consequences on the bioavailability of these elements are still to be studied. Numerous bacteria were associated with Mn oxides thanks to the exopolymers they produced (Figures 9.5 and 9.6), suggesting that bacteria also seemed to be involved in the Mn biogeochemical cycle. $\mathrm{Mn}$ oxides were also associated with other pollutants such as Pb or Zn (Figure 9.6). Despite its high level of pollution, the Spolic Technosol supports a biodiversity as important as that existing in grasslands (Lucisine et al. 2015). Such biological activity expressed in such pollution context is really an amazing specificity of this Technosol, for which micropedology will help to specify the biogeochemical cycle of the metallic elements.

Biological activity (plant, fauna, microorganisms), together with climatic conditions, is a main pedogenetic factor in such young soils (Néel et al. 2013; Leguédois et al. 2016; Zanuzzi et al. 2009). The impact of biological activity on the evolution of organic matter, both from technogenic and natural origins in Technosols, may be revealed by micropedology. As shown herein, organic matter from compost or colonizing vegetation were degraded by fauna. If micropedologic observations of casts attested that PS were ingested by earthworms in constructed Technosol (Pey et al. 2013), ability of mesofauna to recycle PS still remains to be highlighted. Furthermore, analytical characterization of aggregates could specify the (bio)availability of elements (pollutant or nutrient) and so the link between organic matter dynamics and biogeochemical cycles of elements. Micropedology, by revealing the biological activity, allows us to get a functional approach of the Technosol evolution.

\section{Conclusions}

Efficient characterization using analyses of Technosol thin sections allows us to consider micropedology as a well-adapted approach to (1) monitor the evolution of natural and anthropogenic organic and mineral constituents, (2) highlight soil-forming processes either similar to other natural soils or specific to Technosols such as intensity or simultaneity of several processes, (3) take into account the rapid and intensive changes that could been observed in some Technosols at least in their early stages of development, (4) highlight the pedogenetic processes located at the soil layer boundaries and interfaces. Confronted with overall physicochemical soil analyses, micropedology may improve the management of Technosols, i.e. formulation of Constructed Technosols, monitoring of biogeochemical cycles of pollutants in Technosols developed on highly polluted settling ponds, biochar amendment for soil remediation and preservation of green roof efficiency, as parent materials age. 


\section{REFERENCES}

- Adderley WP, Wilson CA, Simpson IA, Davidson DA. 2010. Anthropogenic features. In: Stoops G, Marcelino $\mathrm{V}$, Mees F, editors. Interpretation of Micromorphological Features of Soils and Regoliths. Amsterdam: Elsevier. p. 569-588.

- Adesodun JK, Davidson DA, Hopkins DW. 2005. Micromorphological evidence for changes in soil faunal activity following application of sewage sludge and biocide. Appl Soil Ecol. 29:39-45.

- Bouzouidja, R, Rousseau G, Galzin V, Claverie R, Lacroix D, Séré G. 2016. Green roof ageing or Isolatic Technosol's pedogenesis? J Soil Sediments. doi:10.1007/ s11368-016-1513-3.

- Huot H, Simonnot MO, Morel JL. 2015. Pedogenetic trends in soils formed in technogenic parent materials. Soil Sci. 180:182-192.

- Huot H, Simonnot MO, Watteau F, Marion P, Yvon J, De Donato P, Morel JL. 2014. Early transformation and transfer processes in a Technosol developing on iron industry deposits. Eur J Soil Sci. 65:470-484.

- IUSS Working Group WRB. 2006. World reference base for soil resources 2006. World Soil Resources Reports No. 103. Rome: FAO.

- IUSS Working Group WRB. 2015. World Reference Base for Soil Resources 2014, update 2015. International soil classification system for naming soils and creating legends for soil maps. World Soil Resources Reports No. 106. Rome: FAO.

- Jangorzo NS, Schwartz C. Watteau F. 2014. Image analysis of soil thin sections for a non-destructive quantification of aggregation in the early stages of pedogenesis. Eur J Soil Sci. 65:485-498.

- Jangorzo NS, Watteau F, Hajos D, Schwartz C. 2015. Nondestructive monitoring of the effect of biological activity on the pedogenesis of a Technosol. J Soil Sediments 15(8):1705-1715.

- Jangorzo NS, Watteau F, Schwartz C. 2013. Evolution of the pore structure of constructed Technosol during early pedogenesis quantified by image analysis. Geoderma 207-208:180-192.

- Jongerius A, Heinzberger G. 1975. Methods in soil micromorphology. Soil survey papers 10 . Wageningen. $48 \mathrm{p}$.

- Leguedois S, Séré G, Auclerc A, Cortet J, Huot H, Ouvrard S, Watteau F, Schwartz C, Morel JL. 2016. Modelling pedogenesis of Technosols. Geoderma 262:199-212.

- Lucisine P, Lecerf A, Danger M, Felten V, Aran D, Auclerc A, Gross EM, Huot H, Morel JL, Muller S. 2015. Litter chemistry prevails over litter consumers in mediating effects of past steel industry activities on leaf litter decomposition. Sci Total Environ. 537:213-224.

- Macphail RI, Courty MA, Gebhardt A. 1990. Soil micromorphological evidence of early agriculture in northwest Europe. World Archaeol. 22:53-69.

- Mazurek R, Kowalska J, Gasiorek M, Setlak M. 2016. Micromorphological and physico-chemical analyses of cultural layers in the urban soil of a medieval city - A case study from Krakow, Poland. Catena 141:73-84.

- Monger HC, Cooke PH. 2013. Soil micromorphology and the Anthropocene-Cross scale connections and technology. Span J Soil Sci. 3(2):1-13.

- Morel JL, Chenu C, Lorenz K. 2014. Ecosystem services provided by soils of urban, industrial, traffic, mining, and military areas (SUITMAs). J Soil Sediments 15(8):1-8.

- Néel C, Bril H, Courtin-Nomade A, Dutreuil JP. 2003. Factors affecting natural development of soil on 35-year old sulfide-rich mine tailings. Geoderma 111(1):1-20.

- Pagliai M, Vittori Antisari L. 1993. Influence of waste organic matter on soil micro and macrostructure. Bioresource Technol. 43:205-213.

- Pey B, Cortet J, Watteau F, Cheynier K, Schwartz C. 2013. Structure of earthworm burrows related to organic matter of a constructed Technosol. Geoderma 202203:103-111.

- Prokof'eva TV, Poputnikov VO. 2010. Anthropogenic Transformation of Soils in the Pokrovskoe-Streshnevo Park (Moscow) and Adjacent Residential Areas. Eurasian Soil Sci. 43(6):701-711.

- Pulleman MM, Six J, Uyl A, Marinissen JCY, Jongmans AG. 2005. Earthworms and management affect organic matter incorporation and microaggregate formation in agricultural soils. App Soil Ecol. 29:1-15.

- Rees F, Sterckeman T, Morel JL. 2015. Root development of non-accumulating and hyperaccumulating plants in metal-contaminated soils amended with biochar. Chemosphere 142:48-55.

- Ringrose-Voase AJ. 1991. Micromorphology of Soil Structure: Description, Quantification, Application. Aust J Soil Res. 1991(29):777-813.

- Schwager J, Ouros A, Begin JC, Ruban V, Watteau F, Morel JL. 2013. Sedums role in metal retention and emission by green roofs. In: Book of Abstracts of the 11th International Phytotechnologies Conference; 2014 Sep 30-Oct 3; Heraklion, Crete, Greece; p. 302.

- Séré G, Schwartz C, Ouvrard S, Renat JC, Watteau F, Villemin G, Morel JL. 2010. Early pedogenic evolution of constructed Technosol. J Soil Sediments 10:1246-1254.

- Stoops G, Marcelino V, Mees F, editors. 2010. Interpretation of Micromorphological Features of Soils and Regoliths. Amsterdam: Elsevier. 720 p.

- Watteau F, Villemin G. 2011. Characterization of organic matter microstructure dynamics during co-composting of sewage sludge, barks and green waste. Bioresource Technol. 102:9313-9317. 
- Watteau F, Villemin G, Bartoli F, Schwartz C, Morel JL. 2012. 0-20 $\mu \mathrm{m}$ aggregate typology based on the nature of aggregative organic materials in a cultivated silty topsoil. Soil Biol Biochem. 4:103-114.

- Zanuzzi A, Arocena JM, van Mourik JM, Faz Cano A. 2009. Amendments with organic and industrial wastes stimulate soil formation in mine tailings as revealed by micromorphology. Geoderma 154:69-75. 